\title{
On the refractive indices of some substances for very short electrical waves
}

\section{Dr. A. Lampa}

To cite this article: Dr. A. Lampa (1896) On the refractive indices of some substances for very short electrical waves, Philosophical Magazine Series 5, 42:255, 207-208, DOI: $10.1080 / 14786449608620907$

To link to this article: http://dx.doi.org/10.1080/14786449608620907

曲 Published online: 08 May 2009.

Submit your article to this journal $\sqsubset x$

Џ Article views: 3

Q View related articles $₫$ 
II. On Palcacis humilis, sp. nov., a new Perforate Coral; with Remarks on the Genus. III. On the Jaw-apparatus of an Annelid, Eunicites Reidii, sp. nov.' By George Jennings Hinde, Ph.D., F.G.S.

2. 'The Eocene Deposits of Dorset.' By Clement Reid, Esq., F.L.S., F.G.S.

The new survey of the western end of the Hampshire Basin shows that the Reading Beds become fluviatile and gravelly in Dorset (as was already known), and contain, in addition to Chalk flints, many fragments of Greensand chert. The London Clay thins greatly and becomes more sandy, but is apparently still marine. The Bagshot Sands become coarser and more fluviatile, changing rapidly west of Moreton Station, till they consist mainly of coarse subangular gravel. These gravels, formerly referred to the Reading Series, are now shown to be continuous with the Bagshot Sands, which as they become coarser cut through the London Clay and Reading Beds to rest directly on the Chalk. The Bagshot gravels contain, besides Chalk flints and Greensand chert, fragments of Purbeck marble and numerous Palœozoic grits and other stones probably derived from the Permian breccias of Devon.

Thus there is evidence of disturbance and overlap in Cretaceons or early Eocene times, causing. Reading Beds to rest on Upper Greensand. Later disturbances allowed the Bagshot river to cut into Greensand, Wealden, Purbeck, Permian breceia, Culm Measures, and granite. Folding of the strata seems to have taken place during at least four different periods in the district between Dorchester and Weymouth, which appears to have been a region of special weakness.

The Eocene gravels contain all the foreign rocks known to occur in the Plateau-gravels between Brighton and Dorchester. The fragments of Greensand chert, so abundant in the Plateau-gravels, have not been derived, as supposed, from the central axis of the Weald. They come, as already-formed pebbles, from the Eocene of Dorset, and originally from the Greensand of Devon.

2. 'Discovery of Mammalian Remains in the Old River-gravels of the Derwent near Derby.'-Part I. By H. H. Arnold-Bemrose, Esq., M.A., F.G.S.

\section{Intelligence and Miscellaneous Articles.}

\section{ON IBE REFRACTIVE INDIOES OF SOME SUBSTANCES FOR VERY} SHORT ELECTRICAL WAVES. BY DR, A. LAMPA.

TWHE wave-length of the rays of electrical force used was 8 millim. This number follows from the dimensions of the exciter, but was also ascertained by means of an interference experiment. In reference to the arrangement of the experiments, it may be observed that a coherer was used for demonstrating the electrical rays. Experiments showed that in the experiment on refraction it is possible to get a pretty sharp adjustment for the maximum 
action on the coherer; and hence the arrangement was used for some quantitative determinations.

The refractive indices of a series of solid and liquid substances were determined. The following values were obtained for the wavelength in question corresponding to a value of $\mathrm{N}=37.500 \times 10^{6}$.

\begin{tabular}{|c|c|c|}
\hline Paraffine $\ldots \ldots \ldots \ldots \ldots$ & $n=1.524$ & $n^{2}=2 \cdot 32$ \\
\hline Ebonite .... & $1 \cdot 739$ & $3 \cdot 02$ \\
\hline Crown-glass & $2 \cdot 381$ & $5 \cdot 16$ \\
\hline Flint-glass . . . . . . . & $2 \cdot 849$ & $8 \cdot 41$ \\
\hline Sulphur . . . . . . . . & $1 \cdot 802$ & $3 \cdot 24$ \\
\hline Benzole .......... & $1 \cdot 767$ & $3 \cdot 13$ \\
\hline Glycerine $\ldots \ldots \ldots$ & $1 \cdot 843$ & $3 \cdot 4$ \\
\hline Oil of turpentine $\ldots \ldots$ & $1 \cdot 782$ & $3 \cdot 17$ \\
\hline Vaseline.......... & $1 \cdot 626$ & $2 \cdot 65$ \\
\hline Oil of almonds $\ldots \ldots$. & $1 \cdot 734$ & $3 \cdot 0$ \\
\hline Absolute alcohol ..... & $2 \cdot 568$ & $6 \cdot 60$ \\
\hline Distilled water . . . . . & 8.972 & 80 \\
\hline
\end{tabular}

- Wiener Berichte, July 1896.

\section{A LECTURE EXPERIMENT ON DIATHERMANCITY.}

BY IR. SILVIO LUSSANO.

A very simple and elegant method of showing to a large audience the transparency or opacity of bodies for calorific radiations is the following, which is based on the change of colour some substances experience by variations of temperature.

Double iodide of silver and mercury is prepared in a fine powder. At the ordinary temperature it has a beautiful canary-yellow colour, changing to a purple-red at the temperature of about $49^{\circ}$, and resuming its original colour when cold. This double iodide is prepared by mixing in molecular proportions the two substances $\mathrm{HgI}_{2}$ and $2 \mathrm{AgI}$, then adding to the mixture alcohol which partly dissolves the mercuric iodide; the magma is then well stirred together in a mortar, alcohol being added from time to time. The mixture, which at first is red, then changes to orange, and, after some time, becomes of a canary-yellow colour; the alcohol is allowed to evaporate, the magma being stirred all the time.

The double iodide thus prepared is spread on cardboard, forming a screen of a canary-yellow colour sensitive to calorific radiations. If, then, this is placed below a metal ball strongly heated, the colour of the screen changes, showing the heating due to the radiations. The same thing takes place if a plate of ebonite is interposed between the ball and the screen; but if a plate of a substance opaque to thermal radiations is placed on the ebonite, the shadow of this plate is projected on the screen, showing a yellow colour on a red ground. In this way it can be understood that it is easy to obtain the projections of athermanous substances enclosed between two ebonite plates.-Communicated by the Author from 'Il Nuovo Cimento', May 1896. 